X線においてはその強度によって随時速度調節を行な j.

以上第 1 号機の概略であるが，さらに今後研究を続け 完全なものを開発してゆき，これを用いて種々の研究を 行なう予定である。

その結果については第 2 報以降順次に発表したいと考 えている.

\section{7. 透視用高輝度蛍光板}

東芝工場

竹内 達夫·勝本 管泰 東芝堀川町工場䧛療所

竹村 尚三

〔緒言]

最近，日本人の体位の向上に加えて，被検者の厚い部 位を透視する頻度がいちじるしく多くなり特性のよいX 線 TV 装置や，明るい螢光板が望まれている．われわれ は透視用简輝度螢光板 (FU) を開発し，その特性と臨床 効果を㭘討した。一般に眼の識別能はWeber-Fechner の法測にしたがうことがみとめられ，視力在 $S$ とると，

$$
S=a \log (C / D)+b \quad a, b: \text { 定数 }
$$

で表わされる。ここで $C$ : 視標の明度, $D$ : 地色の明度 で $C / D$ は対比といわれる。とのととから喑い年ど対比 を大きくするかまたは, 対比の小さいは，明るさを增加 させなければ識別能は问上できない。

[特性]

(稗度) 従来のFS と FU とでは，FU は20\%の輝度 増加があり，それに伴い，眠の識別能の上昇がむたらさ れる。

(残光） FU の残光は $2 / 100$ 秒台で，FS に比し $1 / 3$ 以上 短汃くている。

(鮮鋭度) 徒来のFS に比し, FUのO.T.F は低下 している，とのため静止像，微小部位のボケが大きいが 二重造影, レリーフ像, 特に動く被写体に対しては, FU は有利である。

[結論]

（1）被曝量の減少，曆い被写体に有利である。また， 透視が撮影手段として利用されている現在，この点は非 常汇效果的である。

(2) OT.F は低下しているが，動く被写体には障害と ならない.これは, 残光の短縮, 輝度増加によるものと 思われる。

(3) このととから，運動するむのの O.T.F.について 今後考えて見る。

\section{8. 準高压用増感紙について}

$$
\begin{array}{r}
\text { 東芝放射線東京サービス K.K } \\
\text { 沜田 豊治 }
\end{array}
$$

富士銀行健康管理センター

江川 安蔵・䘏入 文雄

\section{I . 緒言}

エックス線の䛦断は結核の早期発昌から癌の早期発見 に移行したので使用中心管電生は $70 \mathrm{kVp}$ から $80 \mathrm{kVp}$ 亿聥 昇した，増感紙もこれに順応しなければならないのであ るが現在なお従来の増感紙を使用している，そこで試作 品（略号 3H-220）との比較検討した結果を報告するる. II. 徒来の增感紙の特性について

鮮鋭度図 1 亿示す，增感紙の条件図 2 に示す，乙の特 性を $80 \mathrm{kVp}$ 亿しなければならないのである．特に蘚鋭度 用増感紙は中感度用増感紙が $60 \mathrm{kVp}$ の時 $65 \mathrm{kVp}$ である. この管電圧を大にするとき $5 \mathrm{kVp}$ の感度差はそのまま趧 長曲線には乗らないのである。感度差図 3 に示す。

III. 準高压增感紙試作の急義

中感度用 $70 \mathrm{kVp}$ のとき鮮鋭度用は $75 \mathrm{kVp}$ ではなく， $88 \mathrm{kVp}$ でないと同程度の写真は得られないのである，し たがって装置容量に制限ありまた露出時間にあ診断上の 制約があるので必らずしむ使用可能ではない，そこで準 高压の試作老得られたので奏験する。

(1) 実験使用材料

イ。使 用 装 置 東芝 $\mathrm{KXO}-15 \mathrm{H}$

$\begin{array}{rcr}95 \mathrm{kVp} & 4 \mathrm{~mA} & \text { 連続 } \\ 150 & 100 & 1.0 \mathrm{sec}\end{array}$

ロ。使用ファントム 腹部骨入胃ファントム (腹部 $18 \mathrm{~cm}$ )

八，使用增感紙 試作品，中感度用，鮮鋭度用

(2) 実験方法

試作品, 中感度用, 焦鋭度用をそれぞれ䋛 $1 / 2$ に切断し て組み合わせ使用した，写真 $1 ， 2$ 示感度図 4 に示す。.

感度は露出洔間に制約があるため, 総べての条件が許 せる範用で高度のものが望ましい。

（3）濃度比較をミクロホトメーターによって濃度分布 あ測定すると試作品と従来品ではグラフの「キフク」に 相違がある。すなわち、「キフク」の差が大きい程対照度 がすぐれていることがいえる，写真 $3 ， 4$ 价ラフ1，2をし めす．椎骨の点線部分が走查した位置.

（4）試作品之従来品（中感度用）の臨床例, 試作品写 真 5 , 7従来品 (中感度) 写真 6 , 8亿示す, 註, 印画のた め判然としていないがフィル写真では試作品の方が著明 明にすぐれている。

[結語]

以上の実験でいるいろ今後に検討する問題は残したが 
われわれの希望を採り入れ研究した結果，多少なるも診 断能の高揚汇適される確信は得られるむの之思う。

今度の研究に御協力を戴きました東芝砂町工場, キャ ノンカメラ社 KKK誌上を措りして厚く御礼申し上げ ます。

\section{9. 胃集検各方式の検討について}

島根県㕌生部医務予防課

下山 靖司

胃集検については種々の方式が用いられ，それぞれ報 告されているが，完来胃集検は「がん」を発見するのが 目的である。「がん」は早期汇発見しててそ意義があり これの見落しは死につながる，見落しのないようにする ためには，胃の各部のどの病変です余するところなく描 写されているととが大切である。このためにわれわれは 当初より $\mathrm{Ba}$ 小量粘膜像の必要性を考光，さら汇発泡剛 を使用して二重造影を行なうことを種々検討しながら胃 集検を行なってきた，現在の方法はガス $200 \mathrm{~m} l$ を作る 上万発泡剂を使用し始好 Ba $20 \mathrm{cc}$ 飲用後体回転, 腹式 呼吸などを加えつつ腹臥位として, 前壁二重造影像，つ いで背卧位として後壁二重造影像を撮影する。 さらにそ の儘45度内至60度まで寝台を起しし第罒斜位にして，胃 体上部を撮影，葠台を起ししつつ $\mathrm{Ba} 250 \mathrm{cc}$ を飲用させ 立位として正面充盈像をついで腹卧位充盈像, 背卧位二 重造影像, 立位第 I 斜位像之, 計 7 枚を原則として撮影 している，搠しこの法では 1 人当たりの時間む掛り，1 時間当たり平均 $12 な い し 15$ 名しか撮影できない。多人数 （80名以上）の際は，半臥位第且斜位像を省き，背卧位 二重造影像 2 枚を加える．乙の方法によると 1 時間当た り平均18ないし20名は可能なので，1日 100 名位の人員 む撮影している．Ba 小量二重造影像などの診断洒值に ついては集検学会などにおいて発表されているので省略 するが，誩断可能領域は遙汃化拡大向上すると報告され ている，併し粘膜像を加えた撮影法は時間，操作など相 当の努力を必要とするので 1 日 100 名以上の人員の撮影 には学苦を伴うが，徒らに多人数を撮影することを考え るよりむ，啠を重点としてしかむ能率的汇実施するのが 「がえ」検診の本来の姿ではないかと思考するすのであ る. このためには如何なる方法によれば最善であるかさ らに一層の努力をしな初ればならないととを強調すると とすにわれわれに対し絶えず指導，助言を賜わっている 鳥取大学石原内科田中講師, 県立中央病院石田医長江改 めて感謝の意を表する次第である.

\section{X線 TV 装置による胃部間接撮影の検討}

駿河台日本大学病院放射線科
遠藤，文定・高間 良夫

柳橋 紘一・黒羽 隆夫

方法として, X-Ray TV 装置による胃部間接撮影法を $I \cdot I+V i d i c o n$ 方式のI·I間接および M.T.V. 間接と, $\mathrm{I} \cdot \mathrm{O}$ 十螢光板方式の M.T.V 間接について検討した.

上記の各方式について解像力テストチャート(Optiker ๑ Funk Leed Line Test Pattern Nr. $61600.05 \mathrm{~Pb} \mathrm{~mm}$ $0.5 \sim 4.0 \mathrm{Lp} / \mathrm{mm}$ ，および銅線 $0.3 \sim 1.0 \mathrm{~mm})$ およびプラ スチックレリーフ模型を用いて解像力, 画質などを比較 検討した．特にX-Ray TV 系については, シンクロス コープ装置を用い $\mathrm{kVp}$ 扎よび MA 変化によって輝度調 整を行なった，また，各方式による被曝線量および画像 の欠損瀕度, 被写体に上る胃像の比較も合わせて行なっ た.

その結果, 解像力に打いては, 直接, 在来間接（ミラ 一,レンズ系) I·I 間接，M·TV. 間接の順に低下して いたが，在来間接と I·I 閐接はほとんご差がなく，小焦 点効果および拡大撮影によっては $\mathrm{I} \cdot \mathrm{I}$ 間接か優っていた。

また，M・TV 間接においては，I·I+Vidicon 方式の 方が，I・0十螢光板方式よりも解像度は優っていたが, 在 来間接よりも一段〜二段少ってい圤。宫た，被曝線量は 撮影の場合 M·TV, I·I, 在来間接の順にすくなく, 特に $\mathrm{M} \cdot \mathrm{TV}$ 闆接は，在来關接の $1 / 6000, I \cdot I$ 間接の $1 / 600$ 位汇 相当する，透視の場合は I·I 使用の時，普通透視の約 $1 / 6$ 位で岁る。しかし I・I 間接では撮影体位によりますが， 胃像の欠損が見られる. 胃部の画質については在来間接 むI・I間接むほとんど変わらない。

また，M・TV 間接を解像力が，一段〜二段上がれば撮 影方法の検討ととむに実用可能になると思う.

\section{質問}

モニタ一面撮影の場合カメラの露出時間を御知らせ下 ¿い.

(長崎 高尾)

\section{追加}

モニター面間接をより良くするために展示 $114 て ゙$ 出し て扔りますようなテレビのブランキング時にミり秒級の X線曝射をするととと，モニタ一を電気的にバイアスし て暗くして扔き，ブランキングパルスX線によるテレビ 透視中に，適当な時期にシャッターを押せばシンク口接 点が閉ぢた後 $\mathrm{X}$ 線パルスがでるのと同期してモニターの 輝度を電子回路によってバイアスを切るととにより 1 フ レーム (1/30秒) だけ上げる方法を用いて，実質的にる リ秒級のX線露出による画を撮影することにわ扎は成功 しております。

(長崎 高尾)

答 